\title{
Attitude and Needs of Thai People in Selecting Domestic Low-Cost Airlines
}

\author{
Sittichai Charoensettasilp, Chong Wu \\ Department of Management Science and Engineering, School of Economy and Management, Harbin Institute of Technology, Harbin, \\ China. \\ Email: kcsittic@yahoo.com,wuchong@hit.edu
}

Received November $17^{\text {th }}, 2012$; revised December $17^{\text {th }}, 2012$; accepted January $18^{\text {th }}, 2013$

Copyright (C) 2013 Sittichai Charoensettasilp, Chong Wu. This is an open access article distributed under the Creative Commons Attribution License, which permits unrestricted use, distribution, and reproduction in any medium, provided the original work is properly cited.

\begin{abstract}
This research studies about attitude and needs of Thai people in selecting domestic low-cost airlines. 400 randomly selected samples include Thai people living in Bangkok and used to travel by airlines. Research methodology includes random convenience sampling technique that use questionnaire to gather data. At significance level of 0.05 , demographic factors including gender, age, education level, monthly income, and occupation do not affect attitude and needs of Thai people in selecting domestic low-cost airlines. However, service marketing mix (7P's) influence attitude and needs of Thai people in selecting domestic low-cost airlines. Place mostly affects attitude and needs of Thai people in selecting domestic low-cost airlines, following by Product, People, Process, and Physical Evidence which demonstrate similar ranking, while Price and Promotion are among the bottom ranking.
\end{abstract}

Keywords: Domestic Low-Cost Airline; Attitude and Needs of Thai People; Service Marketing Mix

\section{Introduction}

Recently, air transportation is indispensable in travelling as it accommodates business and private transactions in terms of convenience and timeliness. Therefore, competition in airline industry is continually intense; Thai Airways Plc. has launched new airline "Thai Smile Airways" for short-haul distance with affordable price. The official opening was on April $27^{\text {th }}, 2012$, at $1^{\text {st }}$ floor, Fashion Hall, Siam Paragon [1]. Low-cost airlines become strategic move of airline business as companies reduce irrelevant expenses such as crew uniform and in-flight catering so tickets can be offered at competitive price. Moreover, tickets can be sold in advance via internet so company can efficiently manage flight schedules and minimize risk of empty seats. Low-cost airline business in Asia has rapidly grown since recent years. Despite significant development of some airlines, overall situation of business is not promising due to economic crisis that affects both domestic and international transportation [2]. Low-cost airlines in Asia are severely affected by economic recession. The International Air Transport Association (IATA) has stated that aviation business in Asia is now struggling and forecasted to face deficit of three thousand million Dollars this year. How- ever, some low-cost airlines can survive in this situation and passengers are likely to reduce travelling expenses.

In Thailand, there are three low-cost airlines which are Orient Thai Airline or One Two GO, Thai Air Asia with slogan "Anyone can fly" and Nok Air or Sky Asia Co., Ltd. [3]. Most airlines face a hard time during world economic recession, country political instability, a H1N1 flu pandemic. Low-cost airline of Thai government such as Nok Air has adapted marketing of domestic flight by rescheduling the flights and decreasing international flights, airplanes, and cabin crews.

Low-cost airlines have always changed marketing strategies to survive in the business and fulfill customers' needs. Service marketing strategy is considered controllable factor that airlines can apply to enhance customer satisfaction [4]. Service marketing mix: The 7P's consist of Product, Price, Place, Promotion, People or employee, Process, and Physical evidence and Presentation.

Based on this reason, researcher would like to study with the following purposes; to study relationship between demographic factors and opinions and needs of Thai people toward service of domestic low-cost airlines, to study service marketing mix that influence opinions and needs of Thai people toward service of domestic 
low-cost airlines, and to compare and analyze each factor of service marketing mix of Thai people in relation to service of domestic low-cost airlines. Research findings can be applied as basic insights and guidelines for market planning to ensure fulfillment of customer satisfaction and brand loyalty in the long run.

\section{Literature Review}

Attitude refers to likelihood of people who learn to behave in such a way that corresponds to satisfied or dissatisfied conditions toward something. It can be referred to internal feeling that reflects tendency of satisfaction or dissatisfaction toward something such as brand, service. As results of psychological experiment, attitude cannot be apparently observed but requires behaviors of people [5].

Attitude is the internal feeling that people use to evaluate or judge something based on favorable or unfavorable feeling toward people, objects, events, and surrounding situations. People who prefer something will have positive attitude toward such things and, vice versa, people who dislike something will have negative attitude as well [6].

Attitude is the combination of thought, belief, opinion, knowledge, and feeling toward something, someone, or some situations. It is measured in forms of acceptance or denial, and such feeling is likely to cause further behaviors. Therefore, human behavior reflects attitude based on thought, belief, knowledge, experience, background of particular person. Attitude blends belief but not all beliefs become attitude. Attitude of people are categorized as structure which are value system, different people have different attitude toward the same things [7] and attitude also affect buying decision of consumers [8].

Service quality is the excellent service that meets or exceeds customers' needs, thus creating customer satisfaction and customer loyalty [9]. Excellent service based on needs refers to fulfillment of requirement or expectation. Exceeded service means that customers' needs or expectation are completely fulfilled so the service is considered great, impressive, responsive to decision, and high value for money.

Hierarchy of Needs Theory. This theory is created by Abraham Maslow, Psychologist of Brandeis University. His theory is one of the most renowned knowledge, stating that people have consequence of needs from basic to the top ones. The theory consists of three main concepts as follows:

- People have needs and needs influence or motivate behaviors. Only unfulfilled needs can be motive while fulfilled needs are not.

- People's needs have their consequence from basic to complicated ones.

- When basic needs are fulfilled, people are likely to demand higher level [10].

Basic needs are the important factors that define differences among people. Maslow said that basic need is the instinct of people, consisting of 5 levels, from lowest to highest. Human must be satisfied with the lowest level prior to moving to higher level. Individual demand different requirements and one behavior can fulfill various needs simultaneously. Maslow categorized basic needs as follows:

- Safety and security need-People require safety, protection, security of objects, safety from threats, anxiety, and pain.

- Love and belonging need-People demand social acceptance such as love, affection, group involvement.

- Esteem need-People demand respect from others or so called self-esteem.

- Self-actualization need-People expect the highest level of need in doing good things based on appropriateness and individual capability [11].

Marketing mix is the tool that organizations apply to achieve marketing objective among target groups. It consists of product, price, place, promotion, people, physical evidence and presentation, and process [12]. Marketing mix is the motivation that influences decision of consumers to use product or service.

- Product can fulfill needs and requirements of people as seller offer product to customer, and customer gain benefits and value from such products. Commonly, product is categorized into 2 groups which are tangible product and intangible product. Management must select main and additional services that properly satisfy customer needs and remain competitive against those of competitors.

- Place is the environment of service that affect perception of customers in terms of value and benefits of offerings. Place is referred to location and channel of delivering service. Important factors of service delivery include location, speed, and convenience in which service can be offered through email or website.

- Price is the monetary value of product. Customer is likely to compare value and price of service, and decide to purchase if value exceed price. Therefore, service price should be clearly determined in correspond to service level so that customer can understand its difference. Moreover, service provider must concern about non-monetary expense, including time spent in service, unfavorable physical and mental conditions, and dissatisfaction due to under-expected service.

- Promotion is the communication tool that informs or motivates customers to have particular attitude and behaviors and promotion becomes the key factor of relationship marketing. Products without proper communication are likely to fail. Communication plays 
important role in conveying information to customers, promote the possible benefits, and stimulate purchase. Key benefits of communication in service marketing focus on sharing customers how they gain benefits from service, when, where, and how to purchase service.

[13]:

Service marketing mix also has three more factors

- People or employee, this factor requires recruitment, training, and motivation to be capable of creating better customer satisfaction than competitors do. It is about relationship between service provider and customer so employee must be competent and possess attitude to respond to customers, problem-solving skill, be creative and be able to create value to organization. Many services require involvement of both customer and employee such as barber service.

- Process refers to regulations and standard procedures to ensure accurate and quick service.

- Physical evidence and presentation offer overall quality of service in terms of neat attire, polite communication, quick service, and others benefits that customers deserve, to ensure quality, appropriateness, and efficiency. These factors include building, equipment, cloths, etc.

Marketing mix in airlines industry. Services are Deeds, Processes, and Performance. Service are distinguished from products mainly because they are generally produced at the same time as they are consumed, and cannot be stored away or taken. An enhanced marketing mix needs to be deployed. It's not about simply reaching out to customers with the right service. But, it's also about creating that right desire to possess the service. 4P's of marketing mix and 3P's of Service Marketing Mix are

1) Product mix. Design, Quality, Range, Brand name, Features give a feel for the "Product" inside a service wrapper. Consumers are demanding not products, or features of products but the benefits they will be offered. The airline product includes of two types of service:

a) On the ground services.

b) In-Flight services.

2) Place mix, Distribution channels, Methods of distribution, Coverage, Location. Online 24 hour reservation system, Consolidation, Tour operator/Travel Agent, Affiliated with companies.

3) Price mix, List price, Discounts, Commissions, Surcharges, Extras, Premium Pricing, Value for money pricing, Cheap value pricing, Low cost pricing, Apex fares.

4) Promotion mix, Advertising, Airlines advertisement need to keep in mind the image of country, The scenic beauty, Tourist attractions, Rich cultural heritages or which would attract number of tourists.

a) Publicity, The pro, Receptionist, Travel agents, Me- dia people are very important people in publicizing the business.

b) Sales promotion, The travel agents, Tour operators, frontline staffs contribute a lot to the promotion of airlines business.

c) Salesmanship, word of mouth "Customer loyalty ladder".

5) People mix, Competence, Reliability, Caring attitude, Responsiveness, Initiative, Problem solving ability, Goodwill.

6) Process mix, Reservation, Flight information, Facilities at the Airport, Baggage handling, Meal service, Flight entertainment, Deliver quality service.

7) Physical evidence mix, on the ground: Booking offices or ticket counter, Paper work, Brand logo, Tickets. In-flight: Aircraft, Seating configuration, Good innerexteriors, Cleanliness, Uniforms, Ambience, Baggage, Labels or Tag [14].

Related research:

[15] relationships between servicing market factors and passengers' satisfaction with on board beverage service of Thai Airways International Public Company Limited. The study reveals that overall opinion of passengers about on board beverage service of Thai Airways International Public Company Limited and servicing market factors such as Product, Price, Place, People and Physical Evidence are highly agreed apart from promotion which overall is fairly agreed. Passengers' satisfaction with on board beverage service of Thai Airways International Public Company Limited is high both for beverages and services. Comparison of passengers' satisfactory level with on board beverage service of Thai Airways International Public Company Limited according to personal basic factors shows that passengers with different basic personal factors such as gender, education, occupation and income have different levels of overall satisfaction with on board beverage service of Thai Airways International Public Company Limited at 5 percent significance level. Relationships between servicing market factors which consist of Product, Price, Place, Promotion, People, Physical Evidence and Process and passengers' satisfaction with on board beverage service of Thai Airways International Public Company Limited are positively correlated at 5 percent significance level in all aspects.

[16] factors on marketing mix affecting customers' final decisions on airline services of airport authority of Thailand cooperation in Muang district Chiang Mai Province. The study reveals that the customers' final decisions were at a highest level in term of the product and the staff's services whereas their marketing promotion was at a lowest level. As compared with each aspect, it was stated that airline reputation and imaged were at a highest level in terms of the product. In terms of price, 
clarified airline tickets were at a highest level. In terms of place, easy-to-buy airlines tickets were at highest level. In terms of the marketing promotion, changeable flight schedules with no charge of fees were at a highest level. In terms of the process, on-time schedules of embarking and landing flights were at a highest level. In terms of the physical characteristics, modern airline equipments were at a highest level. In terms of the staffs' services, the staffs' neat dressing, and their service mind were at a highest level.

\section{Research Objectives}

- To study relationship between demographic factors and opinions and needs of Thai people toward service of domestic low-cost airlines.

- To study service marketing mix that influence opinions and needs of Thai people toward service of domestic low-cost airlines.

- To compare and analyze each factor of service marketing mix of Thai people in relation to service of domestic low-cost airlines.

\section{Research Hypothesis}

- Demographic factors influence opinions and needs of Thai people toward service of domestic low-cost airlines.

- Each factor of service marketing mix significantly affects opinions and needs of Thai people toward service of domestic low-cost airlines in different levels.

\section{Research Methodology}

\subsection{Sampling and Questionnaire}

Samples include Thai people living in Bangkok who used to travel by air transportation. Random convenience sampling method is applied to recruit samples. Size of samples is calculated by estimating population proportion. In case that population is large, $\mathrm{p}$ and q equal to 0.5 , confidence level $95 \%(Z=1.96)$, error less than $5 \%(\mathrm{e}=$ $0.05)$, samples then comprise of 384 persons so the size is enlarged to 400 samples to ensure significant number for factor analysis [17]. Questionnaire is used to gather data in which it is divided into 2 parts as follows;

1) Instruction and guidelines which include research objective, how to fill questionnaire, etc.

2) Questions are divided into 2 parts which are

a) Part 1: Personal data.

b) Part 2: Questions indicating attitude and needs in selecting domestic low-cost airlines based on marketing mix, 7P's.

The questions in part 2 apply rating scale, or Likert's Scale which includes 5 levels (Highest, High, Neutral, Low, Lowest). 70 questions containing 7 factors of ser- vice marketing mix are as follows: Product: 2 parts include on-ground service, 10 questions, and in-flight service, 3 questions. Place: 8 questions. Price: 7 questions. Promotion: 6 questions. People: 9 questions. Process: 14 questions. And physical evidence, 2 parts on-ground service, 5 questions, and in-flight service, 8 questions.

\subsection{Research Instrument Testing}

Validity is tested in terms of content and wording. Pretest is applied by distributing questionnaires to 35 samples to find error, remove low-confidence questions, and adjust some questions to ensure accuracy prior to research. Reliability of questionnaire is tested by using Chronbach's Alpha coefficient [18], 35 questionnaires shown 0.851 confidence level.

\subsection{Data Collection}

Adjusted questionnaires are used for data collection, with more than the number specified in research methodology so as to remove unqualified ones. Collected questionnaire will be coded and data will be recorded and analyzed by using statistical program [19].

\subsection{Research Statistics}

Statistical methods to be used in this research include:

- Descriptive statistics, frequency, percentage, mean, mean ranking and standard deviation.

- Inferential Statistics. This method can be used to test hypothesis. Initially, assumption of statistics will be tested prior to testing hypothesis. Hypothesis of population in this research is about mean of 2 groups of population, using t-test, one way analysis of variance, and Turkey's multiple comparison method.

\section{Research Results}

Research analysis is divided into 2 parts:

- Part 1: Demographic factors of respondents, using descriptive statistics.

- Part 2: Hypothesis testing, using inferential statistics.

Part 1: Demographic factors of respondents, using descriptive statistics.

Table 1 shows that proportions of Thai female and male respondents are $54.0 \%$ and $46.0 \%$ respectively; most of them are in age range of 41 - 50 years, $35.3 \%$ while proportions of $31-40,21-30$, below 21 years, and over 50 years are $31.8 \%, 28.3 \%, 2.8 \%$, and $2.0 \%$ respectively. Most respondents earned Bachelor degree at $48.0 \%$ while percentages of education which is higher and lower than Bachelor degree are 39.5\% and 12.5\%. Proportions of monthly income in range of 30,001 50,000 Baht, 50,001 - 70,000, 15,001 - 30,000, over 70,000, and below 15,000 Baht are 31.8\%, 27.5\%, 25.0\%, 
$13.8 \%$, and $2.0 \%$ respectively. Proportions of occupations are private firm/business owner, state enterprise, government officer, students, and others (housewife/retired) are $51.0 \%, 27.0 \%, 18.3 \%, 2.8 \%$, and $1.0 \%$ respectively.

Based on 7 service marketing mix, factors that influence opinions and needs of Thai people toward service of domestic low-cost airlines are as follows:

Table 1. Frequency and percentage of respondents, by demographic characteristics.

\begin{tabular}{|c|c|c|}
\hline Demographic factors & Frequency & Percentage \\
\hline \multicolumn{3}{|l|}{ Gender } \\
\hline Male & 184 & 46.0 \\
\hline Female & 216 & 54.0 \\
\hline Total & 400 & 100.0 \\
\hline \multicolumn{3}{|l|}{ Age ranges } \\
\hline Less than 21 years & 11 & 2.8 \\
\hline $21-30$ years & 113 & 28.3 \\
\hline $31-40$ years & 127 & 31.8 \\
\hline $41-50$ years & 141 & 35.3 \\
\hline More than 50 years & 8 & 2.0 \\
\hline Total & 400 & 100.0 \\
\hline \multicolumn{3}{|l|}{ Education level } \\
\hline Less than bachelor & 50 & 12.5 \\
\hline Bachelor & 192 & 48.0 \\
\hline Postgraduate & 158 & 39.5 \\
\hline Total & 400 & 100.0 \\
\hline \multicolumn{3}{|l|}{ Monthly income } \\
\hline Less than 15,000 Bath & 8 & 2.0 \\
\hline $15,001-30,000$ Bath & 100 & 25.0 \\
\hline $30,001-50,000$ Bath & 127 & 31.8 \\
\hline $50,001-70,000$ Bath & 110 & 27.5 \\
\hline More than 70,000 Bath & 55 & 13.8 \\
\hline Total & 400 & 100.0 \\
\hline \multicolumn{3}{|l|}{ Occupation } \\
\hline Students & 11 & 2.8 \\
\hline Government officer & 73 & 18.3 \\
\hline State enterprise & 108 & 27.0 \\
\hline $\begin{array}{c}\text { Private } \\
\text { organization/business owner }\end{array}$ & 204 & 51.0 \\
\hline Others: housewife, retired & 4 & 1.0 \\
\hline Total & 400 & 100.0 \\
\hline
\end{tabular}

Product - Respondents focus on reliability of airlines, aviation background in term of safety, and availability of flight schedules, respectively.

Place-Respondents focus on convenience in terms of ticket availability and payment, call center for providing advices and 24-hour reservation, and sufficient distributor, respectively.

Price-Key insights are about reasonable fare compared with service, various levels of fare, and affordable fare compared with other airlines.

Promotion-Key insights are about special fare on continuous basis, promotion such as privilege, mileage program, transportation service, and advertising through various media, respectively.

People-Key focus areas are friendly cabin crews, service-minded cabin crews, and problem-solving ability of cabin crews respectively.

Process-Respondents focus on convenience and speed of check-in process, convenience of luggage claim, and delivery of service quality, respectively.

Physical evidence-Key areas of focus include politeness and friendliness of check-in staff, accuracy and speed of check-in process, well-arranged and comfortable seats on board, well-organized, convenient, and quick documentation, sufficient and easy-to-use shelf space for baggage

Part 2: Hypothesis testing, using inferential statistics.

There are 6 research hypotheses to assume population as follows:

H1: Attitude and needs of Thai people in selecting domestic low-cost airlines are different by gender

H0: $\mu 1=\mu 2$

$\mathrm{H} 1: \mu 1 \neq \mu 2$

From Table 2, Hypothesis result shows that $(\mathrm{t} 398=$ $0.615, \mathrm{p}=0.539$ ). As $\mathrm{p}$-value $>0.05$, so $\mathrm{H} 0$ should be accepted at significance level of 0.05 . It can be referred that Thai males and females have similar level of attitude and needs in selecting domestic low-cost airlines. That means gender factor does not effect on the attitude and the need of Thai people in selecting their domestic lowcost airlines.

H2: Attitude and needs in selecting domestic low-cost airlines are different by age ranges.

H3: Attitude and needs in selecting domestic low-cost airlines are different by education level.

Table 2. Test of mean difference of attitude and needs of Thai people in selecting domestic low-cost airlines, by gender.

\begin{tabular}{ccccccc}
\hline Gender & Number & Mean & $\begin{array}{c}\text { Standard } \\
\text { Deviation }\end{array}$ & $\mathrm{t}$ & df & Sig \\
\hline Male & 184 & 4.10 & 0.92 & 0.615 & 398 & 0.539 \\
Female & 216 & 4.09 & 0.96 & & & \\
\hline
\end{tabular}


H4: Attitude and needs in selecting domestic low-cost airlines are different by monthly income.

H5: Attitude and needs in selecting domestic low-cost airlines are different by occupation.

H6: Attitude and needs in selecting domestic low-cost airlines are different by each factor of service marketing $\operatorname{mix}(7 \mathrm{P}$ 's).

H0: $\alpha i=0$ when $i=1,2,3, \cdots, \mathrm{k}$

H1: $\alpha i \neq 0$

From Table 3, H2: hypothesis testing shows that age range variable got $(\mathrm{F}(4,395)=1.684, \mathrm{p}=0.153)$. As $\mathrm{p}$ value $>0.05$, so $\mathrm{H} 0$ should be accepted at significance level of 0.05 . This result implies that attitude and needs in selecting domestic low-cost airlines are not different by age ranges. That means age ranges factor does not effect on the attitude and the need of Thai people in selecting their domestic low-cost airlines.

H3: hypothesis testing shows that education level variable got $(\mathrm{F}(2,397)=0.940, \mathrm{p}=0.391)$. As $\mathrm{p}$-value $>$ 0.05 , so $\mathrm{H} 0$ should be accepted at significance level of

Table 3. Test of mean difference of attitude and needs of Thai people in selecting domestic low-cost airlines, by age ranges, education level, monthly income, and occupation; using ANOVA.

\begin{tabular}{|c|c|c|c|c|c|}
\hline Source of variation & $\begin{array}{l}\text { Sum of } \\
\text { square }\end{array}$ & df & $\begin{array}{l}\text { Mean } \\
\text { square }\end{array}$ & $\mathrm{F}$ & Sig \\
\hline \multicolumn{6}{|l|}{ Age } \\
\hline Between groups & 290.066 & 4 & 72.516 & 1.684 & 0.153 \\
\hline Within groups & 17010.412 & 395 & 43.064 & & \\
\hline Total & 17300.478 & 399 & & & \\
\hline \multicolumn{6}{|l|}{ Education } \\
\hline Between groups & 81.577 & 2 & 40.788 & 0.940 & 0.391 \\
\hline Within groups & 17218.901 & 397 & 43.373 & & \\
\hline Total & 17300.478 & 399 & & & \\
\hline \multicolumn{6}{|l|}{ Salary } \\
\hline Between groups & 137.263 & 4 & 34.316 & 0.790 & 0.532 \\
\hline Within groups & 17163.214 & 395 & 43.451 & & \\
\hline Total & 17300.478 & 399 & & & \\
\hline \multicolumn{6}{|l|}{ Occupation } \\
\hline Between groups & 48.420 & 4 & 12.105 & 0.277 & 0.893 \\
\hline Within groups & 17252.057 & 395 & 43.676 & & \\
\hline Total & 17300.478 & 399 & & & \\
\hline \multicolumn{6}{|l|}{ Service marketing mix } \\
\hline Between groups & 96.196 & 6 & 16.033 & 268.4 & 0.000 \\
\hline Within groups & 166.835 & 2793 & 0.60 & & \\
\hline Total & 263.032 & 2799 & & & \\
\hline
\end{tabular}

0.05. This result implies that attitude and needs in selecting domestic low-cost airlines are not different by education level. That means education level factor does not effect on the attitude and the need of Thai people in selecting their domestic low-cost airlines.

$\mathrm{H} 4$ : hypothesis testing shows that monthly income variable got $(\mathrm{F}(4,395)=0.790, \mathrm{p}=0.532)$. As $\mathrm{p}$-value $>$ 0.05 , so $\mathrm{H} 0$ should be accepted at significance level of 0.05 . This result implies that attitude and needs in selecting domestic low-cost airlines are not different by monthly income. That means monthly income factor does not effect on the attitude and the need of Thai people in selecting their domestic low-cost airlines.

H5: hypothesis testing shows that occupation variable got $(F(4,395)=0.277, p=0.893)$. As $p$-value $>0.05$, so $\mathrm{H} 0$ should be accepted at significance level of 0.05 . This result implies that attitude and needs in selecting domestic low-cost airlines are not different by occupation. That means occupation factor does not effect on the attitude and the need of Thai people in selecting their domestic low-cost airlines.

H6: hypothesis testing shows that service marketing mix variable got $(\mathrm{F}(6,2,799)=268.405, \mathrm{p}=0.000)$. As p-value $<0.05$, so $\mathrm{H} 0$ should be rejected at significance level of 0.05 . This result implies that attitude and needs in selecting domestic low-cost airlines are different based on each factor of service marketing mix (7P's) for at least 2 aspects. Multiple comparison of Tukey is used to study the differences of such aspects; results are shown as follows:

The results from Table 4 shows that, based on service marketing mix, mean of attitude and needs in selecting low-cost airlines can be categorized into 4 groups; $1^{\text {st }}$ group-Place, $2^{\text {nd }}$ group-Product, People, Process, Physical Evidence, $3^{\text {rd }}$ group-Price, and $4^{\text {th }}$ groupPromotion. Mean of the $1^{\text {st }}$ group is the highest, following by the $2^{\text {nd }}, 3^{\text {rd }}$, and $4^{\text {th }}$ group respectively.

\section{Conclusion and Discussion}

Female is the majority of this in which most of them are

Table 4. Multiple comparison test of Tukey.

\begin{tabular}{cc}
\hline $\begin{array}{c}\text { Each factor of service } \\
\text { marketing mix }\end{array}$ & $\begin{array}{c}\text { Mean of attitude and needs } \\
\text { in selecting service }\end{array}$ \\
\hline Product & $4.1111^{\mathrm{b}}$ \\
Place & $4.4958^{\mathrm{a}}$ \\
Price & $3.9481^{\mathrm{c}}$ \\
Promotion & $3.8585^{\mathrm{d}}$ \\
People & $4.0652^{\mathrm{b}}$ \\
Process & $4.0605^{\mathrm{b}}$ \\
Physical Evidence & $4.0757^{\mathrm{b}}$ \\
\hline
\end{tabular}

Remark: Mean score with different alphabet marked has 0.05 -significance difference. 
in age range of $41-50,31-40$, and 21 - 30 years respectively. Most of respondents earned Bachelor degree, following by those who earn higher and lower than Bachelor degree. Most of respondents have of monthly income in range of 30,001 - 50,000 Baht, following by 50,001 70,000 and 15,001 - 30,000. Private firm/business owner is the main occupation, following by state enterprise and government officer.

Attitude and needs in selecting domestic low-cost airlines are not different by gender, education level, monthly income, occupation. However, attitude and needs have significant difference in term of service marketing mix (7P's) in which mean of attitude and needs toward Place is the highest, following by Product, People, Process, Physical Evidence, Price, and Promotion.

It can be concluded that demographic factors do not affect attitude and needs in selecting domestic low-cost airlines but Thai people focus differently on service marketing mix (7P's) as they concern mostly about Price, then Product, People, Process, Physical Evidence at the same level, following by Price, and Promotion.

\section{Managerial Implications, Limitations and Future Directions}

Qualitative data should be studied with the quantitative data in order to get a more in-depth data in selecting the domestic low-cost airlines of Thai people. However, the consequent problem is the questionnaire that contains excessive questions might bore the respondents and the answers from them may not correspond to the facts.

\section{REFERENCES}

[1] Matichon, "Low-Cost Airlines," 2012. www.matichon.co.th/matichon

[2] Voathai, "Aviation in Thailand," 2012. http://www.voathai.com/content

[3] Thaitransport-Photo, "Low Cost Airlines in Thailand," 2012. http://th.wikipedia.org/wiki

[4] P. Kotler, "Marketing Management," The Millennium
Edition, Prentice-Hall, Upper Saddle River, 2003.

[5] L. G. Schiffman and L. L. Kanuk, "Consumer Behavior," 9th Edition, Prantice-Hall, Upper Saddle River, 2007.

[6] K. Wipada, "Management and Organizational Behavior: Modern Management Techniques," 3rd Edition, Rangsit University, Patumtani, 2008, p. 178.

[7] A. Soitagoon, "Organizational Behavior: Theory and Applications," 4th Edition, Thamasart University, Bangkok, 2007, p. 64.

[8] P. Kotler and G. Armstrong, "Principle of Marketing," 8th Edition, Prantice-Hall, Upper Saddle River, 1999.

[9] C. Chaisompon, "Marketing Services," Se-ed-uktion, Bangkok, 2009, p. 106.

[10] A. H. Maslow, "A Theory of Human Motivation," Psychological Review, Vol. 50, No. 4, 1943, pp. 370-396. doi: $10.1037 / \mathrm{h} 0054346$

[11] A. H. Maslow, "Motivation and Personality," Harper, New York, 1954, p. 236.

[12] P. Kotler, "Marketing Management," The Millennium Edition, Prentice-Hall, Upper Saddle River, 2003.

[13] S. Siriwan, "Strategic Marketing and Strategic Marketing Focus," Tanaratchagorn, Bangkok, 2007.

[14] B. Ghosh, "Service-Marketing-Mix-in-Airindia," 2009. www.docstoc.com

[15] N. Chayphan, "Relationships between Servicing Market Factors and Passengers' Satisfaction with on Board Beverage Service of Thai Airways International Public Company Limited," Phranakhon Rajabhat University, Bangkok, 2008.

[16] M. Sripromnil, "Factors on Marketing Mix Affecting Customers' Final Decisions on Airline Services of Airport Authority of Thailand Cooperation in Muang District Chiang mai Province," Chiangrai Rajabhat University, Chiangrai, 2008.

[17] B. Chanagan, "The Community of Practice Document Faculty of Medicine," Siriraj Hospital, Mahidol University, Bangkok, 2011.

[18] L. J. Chronbach, "Coefficient Alpha and the Internal Structure of Tests," Psychometrika, Vol. 16, No. 3, 1951, pp 297-334. doi:10.1007/BF02310555

[19] W. Karnraya, "Using SPSS for Windows Data Analysis," Thammasarn, Bangkok, 2001. 